\title{
RELASI GENDER DALAM MENGHADAPI BENCANA \\ DI KABUPATEN MALAKA, NUSA TENGGARA TIMUR
}

\author{
Theny I. B. Kurniati Pah ${ }^{1}$
}

\begin{abstract}
Communities in the District of Malaka periodically are hit by floods and droughts caused by climate change. Lack of food makes people have to adjust for the sake of survival. Roles, social relationships, responsibilities and division of labor between men and women also can change when trying to meet the needs of such food as a result of climate change. Matriaki culture is embraced by the people of Malacca and geographical environment often affected influential in the division of labor between men and women every day. Harvard Gender Analysis techniques used in this study to look at the impact of climate change and gender relations are formed in three patterns of food production (production, distribution and consumption) that occurs in the three affected areas in the district of Malaka.
\end{abstract}

Keywords: Disaster, Culture Matriarchy, Gender Analysis Technique Harvard.

\begin{abstract}
ABSTRAK
Masyarakat di Kabupaten Malaka secara periodik diterjang bencana banjir dan kekeringan akibat perubahan iklim. Keterbatasan pangan membuat masyarakat harus menyesuaikan diri demi keberlangsungan hidup mereka. Peran, relasi sosial, tanggung jawab dan pembagian kerja antara laki-laki dan perempuan juga dapat berubah ketika berusaha untuk memenuhi kebutuhan pangan tersebut sebagai akibat perubahan iklim. Budaya matriaki yang dianut oleh masyarakat Malaka dan lingkungan geografis yang sering terkena bencana berpengaruh dalam pembagian kerja antara laki-laki dan perempuan setiap hari. Teknik Analisis Gender Harvard digunakan dalam penelitian ini untuk melihat dampak perubahan iklim serta relasi gender yang terbentuk dalam tiga pola produksi pangan (produksi, distribusi dan konsumsi) yang terjadi pada tiga daerah bencana di Kabupaten Malaka
\end{abstract}

Kata kunci: Bencana, Budaya Matriaki, Teknik Analisis Gender Harvard

\footnotetext{
${ }^{1}$ Pascasarjana Manajemen dan Kebijakan Publik, Universitas Gadjah Mada. email: kurniatipah@gmail.com
} 


\section{PENDAHULUAN}

Bencana menjadi suatu hal yang mengkhawatirkan bagi setiap manusia. Bencana sebagai akibat dari perubahan iklim yang terjadi diberbagai belahan dunia sangat diwaspadai oleh setiap manusia. Namun, bencana merupakan hal yang sulit untuk diprediksi kapan dan bagaimana akan terjadi. Sehingga bagi masyarakat yang sering terkena bencana tentu saja memiliki caranya sendiri dalam menghadapi bencana tersebut.

Perubahan iklim akan semakin berdampak buruk bagi ekosistem dan manusia jika tidak dapat beradaptasi dengan perubahan iklim (Fatkurrohman : 2009). Hal ini pada kenyataanya juga harus dialami oleh masyarakat Kabupaten Malaka yang harus beradaptasi dengan banjir dan kekeringan akibat perubahan iklim. Banjir dan kekeringan selalu menjadi pengalaman yang memprihatinkan pada Kabupaten Malaka di Pulau Timor, tepatnya di Provinsi NTT. Malaka menjadi salah satu dari daerah yang sering menjadi langganan banjir maupun kekeringan.

\section{Bencana, Isu Gender dan Dampak Terhadap Pangan}

Case (2006 dalam Murendo et al, 2011) mengemukakan bahwa perubahan iklim memiliki dampak yang sangat besar pada sektor pertanian, air,energi, transportasi dan kesehatan. Curah hujan yang tak menentu mempengaruhi produksi pertanian (World Bank,2001;FAO, 2008 dalam Murendo, 2011). Perubahan iklim seperti kekeringan dan banjir memiliki pengaruh terhadap ketersediaan pangan di negara berkembang (FAO,2008 dalam Murendo,2011). Ketika perubahan iklim terjadi maka ketersediaan pangan menipis dan hal ini sangat bersinggungan dengan relasi sosial (Alston,2010;Madaha,2012). Alston (2010) lebih lanjut mengatakan bahwa ada perbedaan dampak yang dirasakan laki - laki dan perempuan serta perbedaan respon laki - laki dan perempuan terhadap bencana. Perubahan iklim terjadi, beban kerja perempuan bertambah (Singh et al, 2013).

Isu gender menjadi sangat penting untuk mengkaji dampak dari bencana yang telah terjadi. Pengaruh yang harus direspon dan diadaptasi oleh laki - laki dan perempuan secara berbeda adalah mengenai ketersediaan dan ketahanan pangan. Untuk mengantisipasi kerawanan pangan akibat bencana yang terus menerus terjadi, maka berbagai strategi seperti penyesuaian pola produksi, distribusi, dan konsumsi (Madaha,2012; 
Edward et al, 2011; Murendo et al, 2011; Singh et al, 2013) pangan ditempuh oleh masyarakat. Laki - laki dan perempuan dituntut untuk ikut menyesuaikan diri dalam perubahan iklim karena orang yang telah lama terkena bencana akan mengembangkan mekanisme bertahan hidup (Mahada, 2012). Didukung lagi dengan kondisi masyarakat di Kabupaten Malaka yang menganut budaya Matriakhi menjadikan isu gender penting untuk dikaji dalam penanggulangan akan bencana. Apalagi masyarakat yang tinggal di daerah rawan bencana secara naluri telah memiliki cara untuk merespon kejadian bencana. Hal ini karena kejadian bencana yang beruntun dan periodik mengharuskan masyarakat mampu merespon dan beradaptasi terhadap daerah yang rawan bencana(Partini,dkk 2014).

Alston (2010) mengatakan bahwa ketika perubahan iklim terjadi maka ketersediaan pangan menurun dan bersinggungan dengan relasi sosial yaitu antara laki - laki dan perempuan. Melihat masalah yang telah digambarkan tersebut maka timbulah suatu pertanyaan penelitian mengenai Bagaimana Relasi Gender Dalam Menghadapi Dampak Perubahan Iklim Pada Sektor Pangan Di Kabupaten Malaka Nusa Tenggara Timur. Bukan hanya perempuan saja yang sebagai fokus seperti kebanyakan penelitian khususnya yang berprespektif gender, tetapi bagaimana laki - laki dan perempuan diamati secara bersama - sama dalam beradaptasi pada dampak dari bencana khususnya perubahan iklim.

\section{METODE}

Penelitian ini dilakukan di Kabupaten Malaka Propinsi Nusa Tenggara Timur. Lebih khusus lagi penelitian ini hanya mencakup 3 kecamatan dari 12 kecamatan yang terdapat pada kabupaten Malaka. Dari ke 3 kecamatan ini, dipilih 3 desa berdasarkan daerah paling besar terkena dampak banjir maupun kekeringan, yaitu Desa Umatoos (daerah bencana banjir), Desa Kakaniuk (daerah longsor), Desa Alas Kota Biru (daerah kekeringan). Alasan pemilihan lokasi penelitian ini karena banjir dan kekeringan menjadi bencana yang terjadi secara berkala dan kedua bencana ini terjadi dalam rentang waktu yang tidak begitu jauh berbeda. Selain itu, budaya matriaki yang dipegang pada suku asli Kabupaten Malaka ini juga membuat peneliti ingin mengetahui lebih dalam bagaimana budaya matriaki tersebut berpengaruh dalam penanggulangan bencana yang terjadi. 
Sumber data yang digunakan langsung dari informan melalui proses wawancara mendalam langsung antara peneliti dengan informan. Teknik yang digunakan dalam mengolah dan menganalisis data dalam penelitian ini adalah dengan menggunakan teknik Analisis Gender Harvard. Alasan pemilihan model analisis ini daripada beberapa teknik analisis gender yang lainnya karena model ini tepat digunakan untuk mengetahui dengan baik apa yang dikerjakan laki - laki dan perempuan. Teknik analisis ini dapat mempermudah dalam mengidentifikasi kegiatan spesifik gender dalam pengelolaan pangan, demi mengetahui bagaimana relasi gender dalam menghadapi dampak perubahan iklim yang yang dijabarkan melalui tiga elemen pokok yaitu profil aktivitas, profil akses dan profil kontrol.

Pembahasan mengenai pangan yang diangkat dalam peneitian ini difokuskan pada jagung karena jagung merupakan makanan pokok dari sebagian besar warga Nusa Tenggara Timur.

\section{HASIL DAN PEMBAHASAN}

\section{Kabupaten Malaka Secara Umum}

Malaka merupakan kabupaten yang terbentuk pada tahun 2013. Kabupaten yang masih sangat muda ini merupakan daerah pemekaran dari Kabupaten Belu. Secara administratif, Kabupaten Malaka memiliki 12 Kecamatan, 127 desa dengan luas wilayah 1.160,63 $\mathrm{Km}^{2}$. Kabupaten Malaka beriklim tropis, dengan musim hujan yang sangat pendek (Desember Maret) dan musim kemarau yang panjang (April - Nopember). Sedangkan keadaan topografi Kabupaten Malaka bervariasi antara ketinggian 0 sampai dengan \pm 1500 $\mathrm{m}$ diatas permukaan laut. Variasi ketinggian (0-150 m.dpl) didominasi oleh wilayah Kecamatan Kobalima, Malaka Tengah, Malaka Barat dan Wewiku. Sebagian Wilayah Kecamatan Malaka Barat, Kecamatan Weliman dan sebagian wilayah Kecamatan Malaka Tengah merupakan wilayah DAS Benenai yang menerima banjir bandang setiap tahun.

Sungai Benenai mempunyai panjang \pm 120.75 km, berhulu di Kabupaten Timor Tengah Utara dan Timor Tengah Selatan dan bermuara di laut Timor Kabupaten Belu. Daerah aliran sungai (DAS) Benanai ini sering terjadi banjir. Namun demikian masyarakat di DAS Benanai tersebut berupaya untuk memanfaatkan potensi yang dimilikinya. Salah satu potensi yang dimiliki di daerah aliran sungai (DAS) termasuk DAS Benanai adalah lahan endapan dan resapan air 
tanah. Kedua potensi tersebut dimanfaatkan untuk ditanami dan bahan pangan bagi masyarakat. Oleh karena itu, masyarakat di DAS Benanai berkreasi dan menghasilkan sistem pertanian yang unik. Sistem pertanian yang dikembangkan pada wilayah DAS tersebut adalah sistem usahatani jagung AHUKLEAN.

$$
\begin{aligned}
& \text { Sistem Usaha tani Jagung } \\
& \text { Ahuklean merupakan suatu upaya }
\end{aligned}
$$
(Seran dkk, 2011).
Keuntungan yang dirasakan Kabupaten Malaka karena dilalui oleh aliran sungai Benenai adalah kesuburan tanah yang dapat memenuhi kebutuhan pangan warganya. Tetapi, ada sisi yang buruk juga yang terjadi ketika terjadi hujan yang lebat di daerah hulu (kaki Gunung Mutis) maka yang terjadi di Kabupaten Malaka adalah banjir bandang yang dapat menelan banyak korban jiwa, merusak pertanian dan perumahan serta hilangnya ternak.

\section{Sosio-Kultural Kabupaten Malaka}

Kabupaten Malaka memiliki keunikan tersendiri mengenai keadaan sosio-kulturalnya. Terjadi perbedaan antara adat yang seharusnya dijalankan dengan apa yang dilakukan dalam kehidupan sehari-hari. Pengaruh kemajuan teknologi, ilmu pengetahuan, lingkungan membuat cara pandang masyarakat dan gaya hidup menjadi berubah sedikit demi sedikit. Sama halnya pengaruh lingkungan seperti bencana yang sering menerpa juga menjadi salah satu faktor terjadi perbedaan kehidupan sosio-kultural masyarakat yang dahulu dan masyarakat yang sekarang.

Sebelum berpisah dengan kabupaten Belu dan menjadi kabupaten yang memiliki daerah otonomi sendiri, Malaka 
sering disebut sebagai daerah Belu Selatan. Pada umumnya, adat istiadat yang berlangsung atau dijalankan oleh kedua wilayah ini relatif sama. Tetapi secara spesifik yang membedakan kedua wilayah ini adalah budaya patrilineal yang dijalankan sebagian besar penduduk di wilayah Belu Utara dan budaya matrilineal yang dijalankan di Belu Selatan (Malaka).

Secara sederhana masyarakat Belu dan Malaka memaknai budaya yang mereka anut masing - masing. Patrilineal yang dianut di Belu Utara menekankan patrineal karena pada upacara pernikahan laki - laki harus menyiapkan belis sebagai mahar untuk sang perempuan yang ingin dinikahinya. Berbeda dengan yang terjadi di Malaka, untuk melangsungkan sebuah penikahan maka belis mahar ditiadakan. Hanya sirih pinang yang menjadi pengganti belis pada pernikahan yang dilangsungkan di Malaka.

Bagi orang Malaka, perempuan memiliki posisi dan prestise yang tinggi dalam adat istiadat. Hal ini dapat dilihat dari kepemilikan akan harta benda yang diwariskan kepada perempuan dan bukan kepada laki - laki. Apabila dilangsungkan pernikahan maka tidak seperti biasanya di kebanyakan wilayah yang menganut budaya patriaki yaitu perempuan mengikuti laki - laki tetapi sebaliknya, tetapi laki - laki akan meninggalkan keluarganya dan tinggal di rumah sang perempuan. Untuk hal penting lain seperti kepemilikan marga tidak begitu menjadi persoalan bagi adat istiadat di Malaka. Berbeda dengan yang terjadi pada umumnya diseluruh wilayah Propinsi Nusa Tenggara Timur, marga menjadi hal terpenting dalam sebuah pernikahan. Hal ini dimaksudkan agar dapat menjadi penanda berasal dari keturunan dan suku mana pemakai marga tersebut.

Terkait dengan bencana yang sering terjadi di wilayah Malaka, pengaruh adat istiadat sangat kuat. Apabila bencana banjir terus terjadi maka tua - tua adat akan melakukan ritual adat. Mereka percaya bahwa alam sedang marah kepada mereka sehingga perlu dilakukan ritual ritual adat khusus untuk mengatasi bencana. Demikian pula ketika tidak terjadi banjir, kekeringan berkepanjangan terjadi maka tua - tua adat juga akan berkumpul dan melakukan ritual adat agar dapat mengundang banjir. dalam ritual adat akan disediakan sirih pinang, penyembelihan ayam, babi, sapi maupun kerbau. 
Masyarakat secara turun temurun percaya bahwa banjir merupakan rejeki bagi mereka. Apabila tidak terjadi banjir berarti ada keanehan tersendiri bagi mereka sehingga mereka akan kembali ke adat untuk mengatasi hal tersebut. Penjabat Bupati Malaka yang sangat mengetahui dengan baik keadaan dari penduduk Malaka, juga menjelaskan bahwa Malaka memiliki keadaan lahan pertanian yang subur. Ia juga mengemukakan bahwa masyarakat Malaka memandang banjir dengan dua sisi yang berbeda, yaitu sisi positif dan sisi negatif. Sisi negatif yaitu dapat menghancurkan rumah warga, hilangnya ternak, mata pencaharian, ada korban jiwa, penyakit dan lain sebagainya. Namun, dibalik itu semua ada hal positif yang perlu dilihat yaitu tanah yang subur. Bahkan kabupaten lain hanya memiliki 2 kali musim tanam saja, sedangkan kabupaten malaka memiliki 3 kali musim tanam selama setahun.

Walaupun bencana mengakibatkan kerusakan pada desa tersebut ada hal baik yang diyakini masyarakat yang akan terjadi bagi kehidupan mereka. Mereka selalu mendapatkan pengalaman yang baik setelah bencana terjadi selama bertahun-tahun kejadian ini. Tanah yang subur seolah-olah menjadi jaminan akan kelangsungan hidup mereka. Kebutuhan pangan akan terpenuhi dengan baik untuk bertahan hidup.

Sebagian besar masyarakat sangat menjunjung tinggi adat istiadat di kabupaten Malaka. Budaya matriaki yang menempatkan status perempuan lebih tinggi daripada laki menjadi hal yang lumrah di daerah ini. Namun, budaya matriaki yang dijalankan oleh masyarakat saat ini tidak seperti yang dibayangkan yaitu kebalikan dari budaya patriaki. Dimana dalam segala segi kehidupan baik adat maupun kehidupan sehari-hari status perempuan akan lebih tinggi daripada laki-laki. Budaya matriakhi yang dijalankan hanya sebatas pada waktu atau event tertentu saja seperti penikahan maupun kematian. Dalam keadaan seharihari, laki-laki tetap berperan sebagai pengambil keputusan, kepala keluarga, pencari nafkah dan lain sebagainya. Jadi dalam keadaan sehari-hari laki-laki melakukan peran yang sama seperti yang terjadi pada budaya patriakhi.

$$
\text { Walaupun adat istiadat }
$$
menempatkan perempuan memiliki status sosial yang lebih tinggi daripada laki-laki, pada kenyataannya dalam melaksanakan kegiatan sehari-hari laki-laki tetap menjadi yang utama atau superior 
daripada perempuan. Hal ini terjadi selama bertahun- tahun lamanya dan diterima juga oleh perempuan yang seharusnya mendapatkan tempat yang istimewa secara sosial.

Perempuan dan laki-laki akan terlihat berbeda secara adat, dengan saat melakukan aktivitasnya sehari-hari. Hal ini lah yang membedakan Malaka dari kabupaten lainya. Masyarakat mengganggap mereka menganut budaya matriakhi tetapi yang mereka lakukan hanya sebatas dalam ritual-ritual adat tertentu, dan akan kembali seperti yang terjadi pada budaya patriakhi pada saat melakukan aktivitas sosial dalam kehidupan sehari-hari.

\section{ANALISIS GENDER HARVARD TERHADAP RELASI GENDER DALAM MENGHADAPI DAMPAK BENCANA DI KABUPATEN MALAKA}

Masyarakat pada Kabupaten Malaka umumnya telah memiliki daya adaptasi yang baik dalam menghadapi bencana,baik banjir maupun kekeringan. Namun setelah terjadi bencana ini, adaptasi yang dilakukan masyarakat Malaka umumnya dapat mengakibatkan tertukarnya peran sosial antara laki - laki dan perempuan. Peran sosial yang biasanya dijalankan oleh seorang laki laki pada umumnya, dapat saja dilakukan oleh seorang perempuan. Demikian pula sebaliknya, peran sosial seorang perempuan dapat dijalankan oleh seorang laki-laki, bahkan ada yang dapat menjalankan peran sosialnya secara ganda.

\section{Profil Aktivitas: Perempuan lebih} banyak melakuan aktivitas daripada laki - laki terkait dengan Pangan pada daerah bencana seperti Malaka

Daya adaptasi dengan alam bagi daerah yang sering terkena bencana, mempengaruhi relasi gender seperti cara kerja dan pembagian kerja antara laki-laki dan perempuan terkait dengan pangan. Pada daerah yang sering diterpa banjir seperti desa Umatoos, penanaman bibit dan panen merupakan pekerjaan dari lakilaki. Hal ini didukung oleh kondisi tanah subur dari daerah tersebut namun agak kering khususnya pada musim tanam ketiga. Sehingga apabila dilakukan penanam pangan maka proses penggalian tanahnya harus lebih dalam dari biasanya. Dan laki-laki yang dianggap pantas melakukan pekerjaan tersebut.

Di desa Kakaniuk, bencana seperti longsong tidak begitu berpengaruh dalam produksi pangan yang ada. Bagi mereka 
adanya bencana maupun tidak, persediaan pangan terus dilakukan. Laki-laki sebagai kepala keluarga dianggap sebagai orang yang bertanggung jawab memenuhi kebutuhan keluarga termasuk pangan. Proses produksi pangan memerlukan tenaga ekstra yang biasanya dilakukan oleh laki-laki. Sedangkan perempuan akan melakukan pekerjaan yang lebih ringan tetapi ikut terlibat dalam produksi pangan.

Desa lain yang terkena bencana di kabupaten Malaka adalah desa Kota Biru. Desa ini sering dilanda kelaparan karena bencana kekeringan yang melandanya. Tanah yang gersang didaerah ini menggambarkan sulitnya produksi pangan. Produksi pangan hanya bergantung pada curah hujan setiap tahunya. Letak desa yang jauh dari kebun sebagai tempat produksi pangan membuat laki-laki yang dianggap memiliki sosok yang kuat saja yang dapat menjangkaunya. Perempuan di desa ini tidak begitu banyak mengurusi masalah produksi pangan yang ada. Mereka lebih menyerahkan segala tugas dan pekerjaan produksi pangan kepada laki-laki. Mereka dapat saja pergi ke kebun tetapi tidak sesering yang diakukan laki-laki karena masalah jarak tempuh yang sangat jauh.
Perempuan akan lebih banyak terlibat pada pola distribusi dan pengaturan pola konsumsi. Dalam kedua tahap inilah aktivitas perempuan meningkat. Bahkan aktivitas perempuan lebih banyak daripada laki-laki karena pada ketiga strategi pengelolaan pangan laki-laki hanya memiliki aktivitas yang padat pada tahap produksi pangan saja. Hal ini disebabkan karena perempuanlah yang bagian mengatur, memperhitungkan dengan baik ketercukupan bahan makanan agar dapat mengantisipasi bencana yang dapat terjadi tiba-tiba.

Walaupun jumlah partisipasi atau keterlibatan laki-laki hanya pada pola produksi pangan saja, namun dapat terlihat bahwa laki-laki memegang peranan penting dalam pengelolaan pangan. Perempuan memiliki jumlah keterlibatan yang banyak dalam pengelolaan pangan seperti distribusi dan konsumsi tetapi hal itu tidak berarti apaapa jika terjadinya kegagalan pada pola produksi. Ketersediaan pangan bergantung pada proses produksi yang dilakukan oleh laki-laki. Perempuan akan sulit melakukan tugas distribusi dan konsumsinya apabila gagalnya tugas produksi pangan yang dilakukan oleh laki-laki. 
Profil Akses dan Kontrol: Perempuan

Lebih Banyak Mengakses Dan

\section{Mengontrol Ketersediaan Pangan}

Profil akses dan kontrol dalam penelitian ini, menjelaskan bagaimana laki-laki dan perempuan dapat mengakses dan mengontrol ketersediaan pangan dalam strategi adaptasinya terhadap bencana. Dalam penelitian ini menunjukkan bahwa akses dan kontrol dari laki-laki paling dominan hanya pada pola produksi. Pada pola distribusi dan konsumsi lebih dominan diakses dan dikontrol oleh perempuan.

Pada kenyataan yang terjadi, lakilaki hanya terlibat pada proses produksi dan perempuan pada dua proses setelah itu disebabkan karena penyesuaian mereka akan kondisi alam. Misalnya pada daerah seperti desa Kota Biru, laki-laki lebih dapat mengakses dan mengontrol produksi pangan bukan karena perempuan tidak dapat melakukannya namun karena kondisi geografis dari desa Kota Biru yang letak kebun atau ladangnya berjarak jauh dari rumah. Pada proses selanjutnya yaitu distribusi dan konsumsi lebih banyak dilakukan oleh perempuan. Akses pada dua pola pengelolaan pangan ini terbuka lebar kepada perempuan karena perempuan dapat melakukannya disamping pekerjaan rumahnya seperti memasak, mengasuh anak, mencuci dan lain sebagainya. Perempuan dapat melakukannya tanpa harus menempuh jarak yang jauh.

Dengan akses dan kontrol yang lebih banyak daripada laki-laki, maka menjadikan perempuan lebih banyak menghabiskan waktunya untuk mengelola dan mempersiapkan pangan demi mengantisipasi bencana. Perempuan mengutamakan kesehatan keluarganya dan mengabaikan dirinya sendiri (Alston, 2010). Dengan demikian perempuan harus memiliki kemampuan membagi waktu dengan baik karena disamping mengurus pekerjaan rumah tangganya, perempuan harus memikirkan pengelolaan pangan karena sering dilanda bencana. Kendala yang dialami perempuan pada umumnya adalah pembagian waktu dan ini juga menempatkan perempuan pada posisi berbeban ganda.

Faktor - Faktor yang Berpengaruh: Lingkungan dan Budaya Mempengaruhi Relasi Gender.

Untuk lebih jelas melihat peran perempuan dan laki-laki khususnya pada daerah yang sering tekena dampak 
bencana maka disajikan juga faktor yang berpengaruh yaitu lingkungan dan budaya.

Lingkungan, merupakan faktor yang menyebabkan terjadinya pembagian peran antara laki-laki dan perempuan. Seperti yang telah dijelaskan sebelumnya, keadaan geografis Malaka membuat lakilaki dan perempuan melakukan penyesuaian untuk pengelolaan pangan. Lingkungan mempengaruhi strategi pengelolaan pangan dari laki-laki dan perempuan di Malaka. Pembagian kerja yang terjadi di Kabupaten Malaka menyesuaikan dengan kondisi yang terkena dampak dari lingkungan yang selalu terkena bencana. Pemenuhan kebutuhan pangan juga bergantung pada lingkungan tempat manusia tinggal. Lahan yang subur namun sering terkena bencana juga mempengaruhi pola pembentukan peran antara laki-laki dan perempuan.

Sama halnya dengan lingkungan, budaya juga memiliki pengaruh bagi relasi gender di kabupaten Malaka khususnya dalam pengelolaan pangan. Budaya matriaki yang berlangsung di Malaka hanya berlaku pada saat acara-acara adat saja. Untuk kehidupan sehari-hari

Tabel 1. Faktor Yang Berpengaruh

\begin{tabular}{|c|c|c|}
\hline \multirow[t]{2}{*}{ Faktor } & \multicolumn{2}{|l|}{ Dampak } \\
\hline & Laki-laki & Perempuan \\
\hline Lingkungan & $\begin{array}{l}\text { Laki-laki akan mengerjakan pekerjaan } \\
\text { yang mengeluarkan banyak tenaga fisik } \\
\text { daripada perempuan dalam strategi } \\
\text { pengelolaan pangan, karena } \\
\text { menyesuaikan dengan lingkungan yang } \\
\text { sering dilanda bencana. } \\
\text { Laki-laki hanya terlibat dalam pola } \\
\text { produksi saja karena menyesuaikan } \\
\text { kondisi lingkungan }\end{array}$ & $\begin{array}{l}\text { Perempuan lebih berperan } \\
\text { untuk mengamankan } \\
\text { persediaan pangan karena } \\
\text { lingkungan yang sering } \\
\text { dilanda bencana. } \\
\text { Seperti yang terjadi pada } \\
\text { pola distribusi dan konsumsi. }\end{array}$ \\
\hline Budaya & $\begin{array}{l}\text { Laki - laki didominasi oleh perempuan } \\
\text { karena hanya terlibat pada satu strategi } \\
\text { pengelolaan pangan saja yaitu pola } \\
\text { produksi. Hal ini disebabkan karena } \\
\text { faktor budaya berpandangan bahwa } \\
\text { perempuan hanya bertugas untuk } \\
\text { menenun dirumah. Jadi pergi ke ladang } \\
\text { adalah tugas dari laki-laki. }\end{array}$ & $\begin{array}{l}\text { Perempuan mendominasi } \\
\text { penanganan penegelolaan } \\
\text { pangan pada pola distribusi } \\
\text { dan konsumsi karena } \\
\text { pekerjaan tersebut dapat } \\
\text { dilakukan berdampingan } \\
\text { dengan pekerjaan rumah } \\
\text { tangga, dan tugas menenun } \\
\text { juga tidak terabaikan. }\end{array}$ \\
\hline
\end{tabular}


perempuan tetap mengerjakan hal-hal yang umumnya dijumpai di daerah-daerah berbudaya patriaki. Akan tetapi dalam kehidupan sehari-hari relasi gender yang terjadi menempatkan perempuan paling banyak memegang dominasi atas laki-laki khususnya dalam pengelolaan pangan. Dilihat dari profil aktifitas, akses setra kontrol yang dipaparkan diatas menunjukan bahwa laki-laki hanya terlibat dalam salah satu strategi pengelolaan pangan demi mengantisipasi dampak bencana alam. Kesempatan terbesar laki-laki terlibat dalam pengelolaan pangan adalah pada saat produksi pangan. Pola selanjutnya yaitu distribusi dan konsumsi hanya sebatas membantu perempuan saja. Keterbatasan laki-laki untuk terlibat dalam pegelolaan pangan ini membuat laki-laki seolah berada dalam dominasi perempuan. Walaupun demikian, laki-laki memiliki peran yang cukup penting, yaitu memproduksi pangan. Dimana dapat dilihat bahwa pola distribusi dan pola konsumsi sangat bergantung pada pola produksi, dan pola produksi tersebut dilakukan oleh laki - laki.

Budaya yang memiliki pandangan bahwa perempuan hanya menenun dirumah seolah menempatkan perempuan pada posisi yang istimewa. Apalagi didukung oleh lingkungan yaitu lokasi kebun yang jauh, kondisi tanah pada saat menanam hanya bisa dilakukan oleh lakilaki dan anggapan bahwa produksi pangan merupakan kerja kasar sehingga pantas dilakukan oleh laki-laki.

\section{Manfaat Praktis dan Strategis Relasi Gender}

Relasi gender yang terjadi di Kabupaten Malaka khususnya dalam mengahadapi dampak terhadap perubahan iklim mempunyai beberapa manfaat. Manfaat tersebut dapat dikategorikan menjadi manfaat praktis dan manfaat strategis.

Manfaat praktis dapat berupa pemenuhan kebutuhan pangan sehari hari. Untuk pemenuhan konsumsi sehari-hari maka sangat bergantung pada pola produksi, distribusi dan konsumsi. Namun dari ketiga pola strategi pengelolaan pangan yang berlangsung di Kabupaten Malaka, dapat dilihat bahwa pola produksilah yang paling memiliki peran yang sangat penting. Pola ditribusi dan konsumsi tidak dapat berjalan dengan baik dan pemenuhan akan kebutuhan pangan sehari-hari akan terganggu apabila gagalnya proses produksi pangan. Pola produksi yang di yang terjadi di kabupaten Malaka banyak dilakukan oleh laki-laki. 
Sehingga dapat dilihat bahwa laki-laki memiliki peran yang penting daripada perempuan dalam pemenuhan kebutuhan pangan sehari-hari atau dalam mendapatkan manfaat praktis dari pengelolaan pangan. Akibat dari penyesuaian akan lingkungan, menempatkan laki-laki yang memiliki peran penting dalam pemenuhan ketersediaan pangan agar dapat mengantisipasi datangnya bencana akibat perubahan iklim.

Adapun manfaat strategis atau merupakan manfaat jangka panjang yang mengubah posisi sub-ordinat, yang dapat diperoleh dengan melihat relasi gender dalam menghadapi dampak perubahan iklim di Kabupaten Malaka. Dari pembahasan dan analisis yang telah dipaparkan diatas, dapat dilihat bahwa perempuan yang memiliki partisipasi, kontrol dan akses yang lebih besar daripada laki-laki dalam pemenuhan pangan. Dalam ketiga pola produksi, distribusi, dan konsumsi perempuan yang paling dominan berperan daripada lakilaki sehingga menempatkan laki-laki pada posisi yang tersub-ordinatkan. Pemenuhan ketersediaan pangan banyak dikelola oleh perempuan daripada laki-laki. Perempuan dianggap sosok yang dapat memerhitungkan dengan baik ketersedian pangan demi mengantisipasi bencana yang mengancam daerah tersebut. Dengan adanya anggapan ini membuat kesempatan laki-laki menjadi sangat terbatas untuk berpartisipasi dalam pengelolaan pangan demi mengantisipasi bencana. Laki-laki hanya dibutuhkan sebagai pekerja dalam memproduksi pangan saja. Setelah itu maka dikendalikan oleh perempuan. Untuk jangka waktu yang panjang, laki-laki akan terus berada dibawah kontrol dari perempuan. Budaya juga menempatkan laki-laki pada posisi sebagai faktor produksi saja. Karena budaya setempat memiliki pemahaman bahwa perempuan memang hanya berada di rumah dengan tugas menenun, sedangkan laki-laki pergi ke kebun. Hal ini didukung dengan kondisi lingkungan sehingga posisi lakilaki menjadi lebih memprihatinkan.

Untuk mengubah posisi laki-laki yang tersubordinasi dari perempuan dalam pegelolaan pangan ini maka perlu diperbaiki relasi antara laki-laki dan perempuan yang telah berlangsung lama. Pembagian kerja antara laki-laki dan perempuan seharusnya dapat seimbang. Walaupun terkendala budaya dan lingkungan, perempuan juga harus terlibat dalam proses produksi. Demikian pula halnya dengan laki-laki. turut serta 
mempelajari bagaimana mengatur akan penyimpanan dan pemilihan konsumsi pangan agar tidak hanya didominasi oleh perempuan.

Hal ini juga dapat dilihat bahwa ada relevansi fenomena dampak bencana dengan relasi gender yang terjadi. Daerah yang terkena dampak bencana seperti kabupaten Malaka dapat menimbulkan keidakadilan gender seperti terjadinya sub -ordinasi yang dirasakan oleh laki-laki dan beban ganda yang dialami oleh perempuan.

\section{SIMPULAN}

Berdasarkan hasil analisis yang dilakukan pada penelitian ini, maka dapat ditarik kesimpulan sesuai dengan pertanyaan penelitian yang dipaparkan pada pendahuluan mengenai relasi gender dalam menghadapi dampak perubahan iklim pada sektor pangan di Kabupaten Malaka Nusa Tengara Timur, yaitu terjadinya ketidakadilan gender yang dirasakan oleh laki-laki dan perempuan. Pada pengelolaan pangan, laki-laki tersub-ordinasi karena laki-laki hanya sebagai faktor produksi dalam pengelolaan pangan saja. Sedangkan dominasi yang dilakukan oleh perempuan dalam pengelolaan pangan juga membuat berbeban ganda. Hal tersebut dapat dijabarkan sebagai berikut :

1. Berdasarkan analisis gender Harvard, perempuanlah yang paling banyak melakukan aktivitas, serta lebih dapat mengakses dan mengontrol hal-hal yang berhubungan dengan kebutuhan praksis gender. Namun hal ini juga yang menjadikan perempuan berada dalam posisi yang rentan karena beban yang dipikulnya untuk memikirkan dan mengatur ketersediaan pangan dalam keluarga agar tetap harus dapat terpenuhi dikala bencana terjadi. Dengan daya adaptasi yang dilakukan membuat perempuan melakukan banyak aktivitas atau kegiatan sehingga memposisikan dia pada kondisi rentan. Laki-laki merasakan ketidakadilan gender karena laki-laki hanya terlibat dalam proses produksi pangan demi memenuhi kebutuhan praktis gender (kebutuhan seharihari). Akses dan kontrol yang hanya sebatas pada pola produksi menempatkan laki- laki lebih didominasi oleh perempuan.

\section{DAFTAR PUSTAKA}

Adger, W.N, Hug,S., Brown,K.,Conway,D., dan Hume 
M. 2003. Adaptation to Climate Change In Developing World. Progress In Development Studies, 3 (3), 179-195.

Alston, Margaret. 2010. Gender and Climate Change In Australia.

Bauhardt, Christine. 2013. Rethinking gender And Nature From A Material(Ist) Perspektive : Feminist Economics, Queer Ecologies And Resource Politics

Bell, P. A., Greene, T. C., Fisher, Jeffrey D., Baun, Andrew. 2001. Environmental Pshycology (Fifth Edition), Fort worth, Hancourt College.

Berry et al., 2011. Climate Change and Farmers' Mental Health: Risks and Responses

Chikulo, BC. 2014. Gender, Climate Change and Energy in South Afrika $\therefore$ A Review.

da Costa. Aplonia Diana Sherly, 2013 Resilience for the Flood Event Based On Comunity Perception ( a case study : in west Malaka Subdistrict of Belu Regency, East Nusa Tenggara Province). Tesis : Universitas Gadja Mada.

Darwin, Muhadjir, M. 2005. Negara dan Perempuan. Reorientasi Kebijakan Publik. Yogyakarta : Grha Guru

Demartoto,Argyo. 2009. Kebutuhan Praktis dan Strategis Gender 'Menyoal TKW Indonesia Yang Akan Dikirim ke Luar Negeri.
Surakarta : Sebelas Maret University Press.

Derbile, Emmanuel Kanchebe., 2012. Reducing vulnerability of rain-fed agriculture to drought through indigenous knowledge systems in north-eastern Ghana.

Drolet and Sampson, 2014. Addressing climate change from a social development approach: Small cities and rural communities' adaptation and response to climate change in British Columbia, Canada.

Dunn, Karen S., 2015. Toward a MiddleRange Theory of Adaptation to Chronic Pain.

Edwadrs et al. 2011. Climate Change Adaptation At The Intersection Of Food And Health.

FAO. 2011. Adapt : Framework Programme on climate Change Adaptation, Rome. FAO Crate \&Nuttal. 2009. Antropologi and Climate Change, California, Left Coast Press, Inc.

Fatimah, Dati. 2008. Gender Mainstreaming Dalam Pengurangan Risiko Bencana. Diakses melalui www.academia.edu pada 22 Februari 2015.

Fatkurrohman. 2009. Pemanasan Global dan Lubang Ozon : Bencana Masa Depan. Yogyakarta : Media Wacana

Handayani, Trisakti., Sugiarti. 2008. Konsep Dan Teknik Penelitian Gender. Malang:UMM Press. 
Harefa, Torotodo. 2014. Dampak Banjir Sungai Terhadap Kesehatan Mayarakat di Kabupaten Nias Utara. Universitas Gadjah Mada : Tesis.

Hayati, et.al., 2010. Coping with Drought: The Case of Poor Farmers of South Iran.

Hidayati., Deni, 2011. Adaptasi dan Mitigasi Masyarakat Pesisir Dalam Menghadapi Perubahan Iklim Dan Deradasi Sumberdaya Laut, Jakarta : Leuser Cita Pustaka.

IPCC.2007. Climate Changes 2007. Impacts, Adaptation and Vulnerability Contribution of Working Group II to the Fourth Assesment Report of the Intergovermental Panel on Climate Changes (IPCC). M.L Parry, OF Canziani. J. P. Palutikof, P.J van der Linden and C.E Hanson (Eds) Cambridge University Press. Cambridge. 200 pp.

Jabeen, Huraera,. 2014. Adapting the built environment: the role of gender in shaping vulnerability and resilience to climate extremes in Dhaka.

Kusmiati, Christiana Yuni. 2005. Мепијu Perbaikan Manajemen

Penanggulangan Bencana Di Indonesia. Diakses di www.academia.edu pada September 2014.

Kusumasari, Bevaola, 2014, Manajemen Bencana dan Kapabilitas Pemerintah Lokal. Yogyakarta : Gava Media.
Larson, et al., 2011. Gendered Perspectives About Water Risks and Policy Strategies: A Tripartite Conceptual Approach.

Madaha, Rasel Mpuya,. 2010. Disparate coping strategies for gendered effects of drought A call for reexamination of gender roles and harmful traditions in Central Tanzania.

Matthews, R.B., M.J. Kropff, T. Horie, and D. Bachelet. 1997. Simulating the Impactof Climate Changes on Rice Production in Asia and Evaluating Options for Adoption. Agric.Syst. 54:399-425.

Megawangi, Ratna. 1999. Membiarkan Berbeda? Sudut Pandang Baru Tentang Relasi Gender. Bandung : Mizan.

Mosse, Julia Cleves. 1993. Gender dan Pembangunan. Yogyakarta : Pustaka Pelajar.

Murendo, et al., 2011. Drought impacts and related risk management by smallholder farmers in developing countries: Evidence from Awash River Basin, Ethiopia.

Murniati, Ktut. 2014. Adaptasi Perubahan Iklim Dan Keterkaitannya Dengan Produktivitas Dan Ketahanan Pangan Rumah Tangga Petani Padi Di Kabupaten Tanggamu. Universitas Gadja Mada : Tesis.

NAS : 2007. Global Warming to Cause More Severe Tornadoes, Storms, Fox News, August 31,2007. 
Nasrullah. 2012. Perubahan Iklim dan Trend Data Iklim. Badan informasi Perubahan Iklim BMKG. http://www.google.com

Nugroho, Riant. 2008. Gender dan Administrasi Publik. Yogyakarta : Pustaka Pelajar.

Numberi, 2009. Perubahan Iklim Implikasinya Terhadap Kehidupan di Laut, Pesisir dan Pulau - Pulau Kecil. Jakarta: Citrakreasi Indonesia.

Nurhaeni, Ismi Dwi Astuti. 2010. Kebijakan Pro Gender. Surakarata : UNS Press.

Peng, S., J. Huang, J.E. Sheelhy, et al. 2004. Rice Yields Decline With Higher Night Temperature from Global Warming. Proc. Natl. Acad. Sci. USA 2004; 101: 9971-9975.

Pitcock, B.A and N.R. Jones. 2009. Adaptation to What and Why / in L. E Shipper \& I. Burton (Eds). Adaptation in Climate Changes (PP.35-62). London.Earthscan.

Puspitawati, Herien. 2013, Konsep, Teori Dan Analisis Gender. Diakses di www.google.com pada 15 April 2015.

Rabiul, et al., 2014. The Changing Role of women in Resilience, Recovery and Economic Development at the Intersection of Recurrent Disaster: A Case Study from Sirajgang, Bangladesh.

Rostyaningsih ,2010, Dipresentasikan dalam acara "Pelatihan Analysis Gender di
Perguruan Tinggi" dalam rangka Program Revitalisasi PSW/G yang diselenggarakan oleh Pusat Penelitian Gender (PPG) LPPM Undip pada tanggal 31 Agustus $\quad-\quad 1$

September 2010 di Semarang diakses pada : admfisipundip.ac.id tanggal 20 Februari 2015

Sari., Mayang Rahmi Novita.,2013 Strategi Adaptasi Penduduk Di Wilayah Kekeringan. Tesis : Universitas Gadjah Mada

Seran, Yohanes Leki., Medo Kote, dan Joko Triastono. 2011. Produktivitas Jagung Dan Pendapatan PetaniPada Sistem Usahatani Jagung Ahuklean Di Daerah AliranSungai Benanai, Kawasan Besikama, NTT. Balai Pengkajian Teknologi Pertanian NTT. Diakses pada Desember 2015.

Singh, Ram., S.M. Feroze, Lala I.P. Ray. 2013. Effects of Drought on Livelihoods and Gender Roles: A Case Study of Meghalaya.

Speranza, C.I. 2010. Resilent Adaptaion to Climate Change in Afrika Agriculture. Bonn : German Developmen Institute.

Surmaini, E., Rakman, dan R. Boer. 2008. Dampak Perubahan Iklim Terhadap Produksi Padi : Studi Kasus Pada Daerah Dengan Tiga ketinggian Berbeda. Prosiding Seminar Nasional dan Dialog Sumberdaya Lahan Pertanian. Balai Besar Penelitian dan Pengembangan 
Sumberdaya Lahan Pertanian, Bogor.

Susuri, Ahmad. 2010. Pemikiran Ekofeminisme dalam prespektif etika lingkungan : relevansinya bagi pelestarian lingkungan hidup Indonesia. UGM : tesis.

Swain, Mrutyunjay dan Mamata Swain,. 2010. Drought Vulnerability, Coping Capacity and Residual Risk: Evidence from Bolangir District in Odisha, India.

Tong, Rosemarie Putnam. 2010. Feminist Thought: Pengantar Paling Komprehensif kepada Arus Utama Pemikiran Feminis. Yogyakarta: Jalasutra

Yogaswara Herry. 2008. Adaptasi dan mitigasi Masyarakat Pesisir Dalam Menghadapi Perubahan Iklim dan Degradasi Sumberdaya Laut : Perubahan Iklim dan Masyarakat Pesisir Kawasan Teluk Bone. Pusat Penelitian Oceanografi- LIPI. Leuser Cipta Pusaka. Jakarta Selatan. 